\title{
EFFECT OF LASER BEAM EXPOSURE ON THE QUALITY OF CATTLE MEAT DURING COLD STORAGE
}

\section{Hassan, H. E. ${ }^{1}$; A. A. Abd El-Rahman' ; M. Diaa El-Din H. Farag ${ }^{3}$; Z. A. Abd El-Salam ${ }^{1}$; F. M. Shehata ${ }^{1}$}

\section{ABSTRACT}

The aim of this research is to study effect of laser exposure on the fresh cattle meat quality during cold storage with respect to survival and growth of bacteria, shelf-life and physiochemical properties. Fresh cattle meat samples were exposed to three doses (9, 18 and $27 \mathrm{W.s} / \mathrm{cm}^{2}$ ) of laser beam with wavelength $450 \mathrm{~nm}$. The obtained results were indicated that: 1) the total account of microorganisms of samples weren't changed at 0 (control) and 9 W.S/ $\mathrm{cm}^{2}$ of laser exposure dose for 5 days of cold storage period. Meanwhile, it was decreased $8.1 \times 10^{6}$ and $8.3 \times 10^{6} \mathrm{CFU} / \mathrm{g}$. of 18 and $27 \mathrm{~W} . \mathrm{s} / \mathrm{cm}^{2}$ laser exposure dose of meat sample, respectively, at extended shelf life of 10 and 15 days of cold storage period, comparing in control sample which was $3.6 \times 10^{6} \mathrm{CFU} / \mathrm{g}$. at 5 days of cold storage period. Also, the physiochemical properties of samples were taken the same trend, 2) the samples were rejected of 0 (control), 9, 18 and 27 W.s/cm ${ }^{2}$ of laser exposure dose at 10, 15, and 20 days of cold storage period, because of the total account of microorganisms of meat was higher than within the acceptable limits. 3) the total account of microorganisms and physiochemical properties of sample at 18 and 27 $W . s / \mathrm{cm}^{2}$ laser dose were within the acceptable limits, and these results lead to increase the beef meat shelf life about 10 and 15 days, comparing with control sample at 5 days of cold storage period., and 4) laser beam exposure can be used to increase shelf life and inspection of meat quality.

Key words: laser exposure, cattle meat quality, cold storage and physiochemical properties.

1. National Institute of Laser Enhanced Sciences (NILES), Cairo University, Egypt

2. Agricultural Engineering Research Institute, Agricultural Research Center (ARC), Giza, Egypt

3. National Center for Radiation Research and Technology (NERRT), Egyptian Atomic Energy, Cairo, Egypt. 


\section{INTRODUCTION:}

$\mathrm{M}$ eat can be define as the whole or part of the carcass of any buffalo, camel, cattle, deer, goat, hare, sheep and poultry, or rabbit, slaughtered, but dose not include eggs, or fetuses (Williams, 2007). The hot and humid climate of Egypt is quite favorable for the growth of numerous insects and microorganisms that destroy stored food and cause spoilage of it. Spoilage can also occur due to chemical and physiological changes during storage of foods especially beef. The fresh meat and meat products are commonly marketed at refrigerated temperatures $\left(2-5^{\circ} \mathrm{C}\right)$. However, many undesirable changes of the products can occur during refrigeration due to microbial growth and lipid oxidation, which give rise to quality reduction, meat spoilage, and economic loss. (U.S. Department of Agriculture and foreign agriculture service, 2013). Recently, a world has been looking for development in technology. LASER is one of these technologies, and there are many applications at several fields such as agriculture, communication and medicine (Du and Sun, 2005).

Cozzolino and Murray (2004) showed that applied VIS/NIR 400-2500 $\mathrm{nm}$ spectra for classifying the meat from beef, lamb, pork, and chicken achieved accuracy was over $80 \%$.

Adams and Moss (2008) concluded that contamination of the meat of slaughtered animals by processing equipments, knives and workers however, less important than contamination from the animals themselves.

Perez-Marin et al. (2009) mentioned that applied NIR for all stages of pigs: the live animal, carcass in slaughterhouse, subcutaneous fat sample with skin, skin-free subcutaneous fat sample, and transverse section.

Aleksić et al. (2011) stated that factors affecting the quality of meat can be divided into ante-mortem (genetic background, housing, nutrition, disease and etc.) and post-mortem (slaughtering procedure, storage and cooling of meat).

Ameral et al. (2013) concluded that the optical methods have the greatest potential since they are fast, nondestructive, and generally low cost. Potential application of laser bio-speckle technique and its methods of image processing can be used to assess and quantify biological phenomena related to beef aging and evaluating quality of meat color. 
Gap-Don et al. (2013) referred to the most quality traits such as drip loss, cooking loss, tenderness, lightness, redness, and moisture content were affected by freeze-thawing. Exudates were positively correlated with total protein content and total plate count but negatively correlated with $\mathrm{pH}$ and cooking loss.

Marcos et al. (2013) said that the surface enhanced laser desorption/ionization time of flight mass spectrometry (SELDI-TOF-MS) considered useful tool to obtain the soluble protein profiles of Longissimus Thoracis (LT) muscles of fresh pork.

Schmidt et al. (2013) approved that the prototype handheld Raman system can be used as a rapid non-invasive optical device to measure raw sheep meat to estimate cooked meat tenderness and cooking loss. The results showed the potential usefulness of Raman spectra which can be recorded during meat processing for the prediction of quality traits such as tenderness and cooking loss.

Wang and Li (2013) referred to the coherent laser has been considered as one of the standard light sources for measuring the optical properties of living tissues.

The objective of the study was to determine the laser exposure effect upon the chemical, physical and color changes in beef meat during cold storage period and to evaluate microbiological quality of laser exposure beef samples during cold storage period.

\section{MATERIALS AND METHODS:}

\section{Sample preparation:}

The fresh cattle samples were obtained from local slaughter house. It was taken from a single male cattle carcass of Egyptian native cattle (Baladi Bullocks), under Egyptian conditions. With (approximately 22 months of age and $430 \mathrm{~kg}$ live weight). The cattle samples were taken from the right carcass side (top round) and were brought to laboratory in cold iced foam box within (24-h post-mortem). Samples were divided into portions about $200 \mathrm{~g}$ weights ( $2 \mathrm{~cm}$ thickness) and packed in tightly sealed polyethylene pouches $(15 \mathrm{~cm} \mathrm{~L} \mathrm{x10} \mathrm{cm} \mathrm{W})$ under atmospheric condition and stored at $1 \pm 4^{\circ} \mathrm{C}$ for $5,10,15$ and 20 days of cold storage, which carried out through-2014. 


\section{Laser setup:}

The experimental setup was developed and assembled in the Laboratory of Laser Application in Agriculture Engineering at National Institute of Laser Enhanced Science (NILES), Cairo University, Egypt. It consists of laser source, beam expander and holders as shown in Fig.(1). Diode laser in the blue visible light with continuous wavelength $450 \mathrm{~nm}$ was used, the output power $5000 \mathrm{~mW}$. The diode laser used gives high intensity to cover the entire cattle meat samples surface area, including the boundaries by using the beam expander.

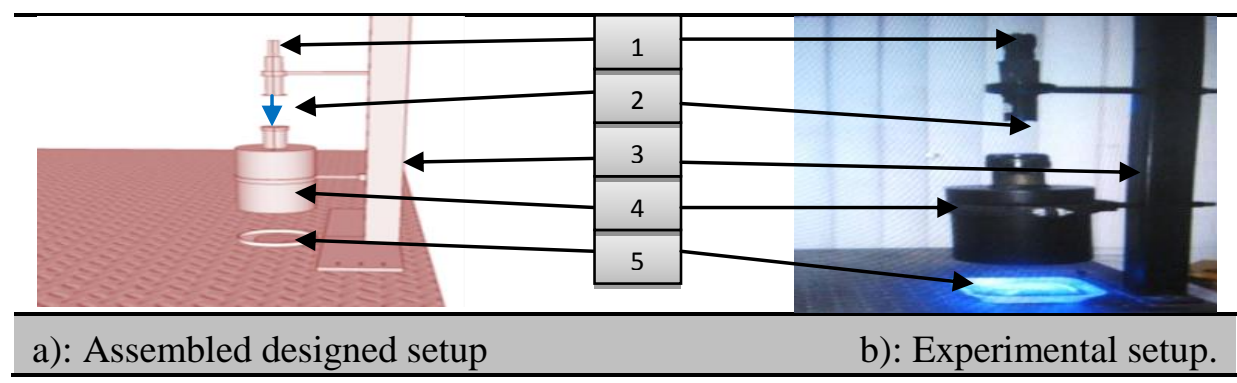

1- Laser source, 2- Laser beam, 3- Copper holder, 4-Beam expander and 5- Cattle sample

Fig. (1): The assembled designed and the experimental setup of laser exposure for cattle samples.

\section{Laser exposure treatment:}

Cattle samples were subjected to different doses of laser beam. The power intensity was determined prior to laser exposure treatment, according to (Al-Watban et al., 2007) by measuring the laser power (W) and the laser spot size $\left(\mathrm{cm}^{2}\right)$ and it was calculated from the following equations (1).

$$
\mathbf{P}_{\mathbf{I}}=\frac{\mathrm{W}}{\mathrm{A}}
$$

Where: $\mathbf{P}_{\mathbf{I}}$ : Power intensity in $\mathrm{W} / \mathrm{cm}^{2} ; \mathbf{W}$ : Laser power $5000 \mathrm{~mW}$ and $\mathbf{A}$ : Laser spot size $10 \mathrm{~cm}^{2}$

The exposure dose of laser beam was determined from the power intensity and the exposure time of laser beam with the cattle meat surface, according to (Al-Watban et al., 2007) and it was calculated from the following equation (2) 


$$
\mathbf{I}=\mathbf{P}_{\mathbf{I}}(\mathbf{T})
$$

Where: I: Laser exposure dose in W.sec/ $\mathrm{cm}^{2}$; $\mathbf{P}_{\mathbf{I}}$ : Power intensity in $\mathrm{W} / \mathrm{cm} 2$ and T: exposure time (180, 360 and 540 seconds).

Variable exposure times were employed to provide different laser doses of 9,18 and 27 W.s $/ \mathrm{cm}^{2}$ to be applied to the surface of the beef meat samples.

Cattle samples were treated on each side, therefore a total laser dose of first treatment $\left(9 \mathrm{~W} . \mathrm{s} / \mathrm{cm}^{2}\right)=2 \times 4.5 \mathrm{~W} . \mathrm{s} / \mathrm{cm}^{2}$ according to (Sommers et al., 2010) and (Escalona et al., 2010).

\section{Storage process:}

Treated and non-treated cattle meat samples were immediately refrigerated stored at $4 \pm 1{ }^{\circ} \mathrm{C}$ and subjected to the periodical analysis at 0 , 5,10 , and 20 days intervals.

\section{Chemical analysis:}

Chemical analyses include of moistures content, protein, collagen, fat, $\mathrm{pH}$ value and thiobarbituric acid value (TBA), were measured as the following:

\section{Moisture content, protein, fat and collagen percentages:}

Sample chemical analysis was performed using Food Scan ${ }^{\mathrm{TM}}$ Pro meat analyzer (Foss Analytical- A/S, Model 78810, and Denmark).

pH measurement, it was measured after $24 \mathrm{hr}$ post-chilling using $5 \mathrm{~g}$ of meat according to the following methodology described by (Abdel-Aziz, 2006). The $\mathrm{pH}$ of the obtained suspension was measured by Microprocessor $\mathrm{pH}$ meter ( $\mathrm{pH} 211$, Hanna instruments, Italy).

Thiobarbituric acid test, it was used to determine the extent of lipid oxidation in chilled beef samples, and the average values were reported as (mg malonaldehyde per $\mathrm{kg}$ beef sample). The method for analysis was described by (Vyncke, 1970). 
PROCESS ENGINEERING

\section{Physical characteristics:}

Water holding capacity percentage, it was measured according to (Sami, 2001). Water holding capacity (\%) can be calculated by the following equation (3):

$$
\text { Water holding capacity, } \%=\frac{w 1-W 2}{W 1} \times 100 .
$$

Where: W1= Weight of meat sample before measuring, $g$ and W2= Weight of meat sample after measuring, g.

Cooking loss percentage, it was determined using two cubes of beef about $100 \mathrm{~g}$, (W3). After boiled process, then beef cooked samples were left to be cool at room temperature. Samples were re-weighed (W4) according to the method described by (Sami, 2001). The Cooking loss (\%) content can be calculated by the following equation (4):

$$
\text { Cooking loss, }(\%)=\frac{w 3-w 4}{w 3} \times 100 .
$$

Where: $\mathbf{W} \mathbf{3}=$ Weight of meat sample before measuring, $\mathrm{g}$ and $\mathbf{W} \mathbf{4}=$ Weight of meat sample after measuring, g.

Shear force, after measuring cooking loss, the cooked samples were used for determining the shear force (kgf) by using Instron Universal Testing Machine (Model 2519-105, USA) according to the procedure outlined by (Shackelford et al., 2004).

\section{Color properties:}

Meat color was measured using Croma meter (Konica Minolta, model CR 410, Japan). Color was expressed using the CIE L, a, and b color system (CIE, 1976). a values measure redness (positive a value indicates a reddish color, while negative value measures greenish); and $b$ values measure yellowness (positive $b$ value indicates a more yellowish color, while negative value measures blueish).

\section{Color measurements:}

Light intensity value, a total of three spectral readings were taken for each sample on different locations of the muscle. L (lightness) values 
measure (higher L value indicates a white color, while lower L value indicates a black color);

Hue degree $(\varphi)$, defined as the angle between the hypotenuse and $0^{\circ}$ on the (blue-green / red-yellow) axis, according to (Balkeniues et al., 2003). Hue angle degree can be computed from the following equation (5):

$$
\varphi=\tan ^{-1}(b / a)
$$

Where: a, (red-green) axis, values and b: (yellow-blue) axis, values.

Saturation ( $\boldsymbol{\sigma})$ was referred to color saturation according to (Balkenius et al., 2003).

This can be calculated from the following equation (6)

$$
\sigma=\sqrt{(a)^{2}+(b)^{2}}
$$

\section{Microbiological analysis:}

The standard method and suitable culture media were used for the microbiological analysis, the counting of microbial colonies was carried out after $48 \mathrm{~h}$ incubation and results were expressed as log values and reported before exceeding acceptable limits, (ISO 4833, 2003).

\section{RESULTS AND DISCUSSION:}

Fig.(2) shows that effect of laser exposure dose on chemical composition of meat during cold storage.

The moisture content percentage of control samples decreased from $77.63,77.23$ and $75.68 \%$ and sample of $9 \mathrm{~W} . \mathrm{s} / \mathrm{cm}^{2}$ dose, it was 77.61 , 77.2 and $75.66 \%$ for $0,5^{\text {th }}, 10^{\text {th }}$ days respectively. For $18 \mathrm{~W} . \mathrm{s} / \mathrm{cm}^{2}$ dose, it was $77.51,76.98,75.41$, and $75.24 \%$ for $0,5^{\text {th }}, 10^{\text {th }}$ and $15^{\text {th }}$ days, respectively. For 27 W.s $/ \mathrm{cm}^{2}$ dose, it was 77.39, 76.61, 75.3, 75.22 and $74.92 \%$ for $0,5^{\text {th }}, 10^{\text {th }}, 15^{\text {th }}$ and $20^{\text {th }}$ days of cold storage period, respectively.

The protein percentages of meat samples were slightly affected by laser exposure dose. Where, the protein percentage of control meat sample decreased from 21.31, 20.62 and $19.99 \%$ and sample of $9 \mathrm{~W} . \mathrm{s} / \mathrm{cm}^{2}$ dose, it was $21.29,20.58$ and $19.99 \%$ for $0,5^{\text {th }}$ and $10^{\text {th }}$ days, respectively. For 
$18 \mathrm{~W} . \mathrm{s} / \mathrm{cm}^{2}$ dose it was $21.27,20.51,19.96$ and $19.35 \%$ for $0,5^{\text {th }}, 10^{\text {th and }}$ $15^{\text {th }}$ days, respectively. For 27 W.s $/ \mathrm{cm}^{2}$ dose, it was $21.25,20.49,19.65$, 19.32 and $19.07 \%$ for $0,5^{\text {th }}, 10^{\text {th }},{ }^{15 \text { th }}$ and $20^{\text {th }}$ day of cold storage period respectively.

The moisture content/protein $(\mathrm{MC} / \mathrm{P})$ ratio proportionally was changed by the applied laser exposure doses and cold storage time; the MC/P ratio of control meat sample increased from 3.64, 3.74 and 3.78 and sample of 9 W.s $/ \mathrm{cm}^{2}$ dose, it was $3.64,3.75$ and 3.78 for $0,5^{\text {th }}$ and $10^{\text {th }}$ days, respectively. For $18 \mathrm{~W} . \mathrm{s} / \mathrm{cm}^{2}$ dose, it was $3.64,3.75,33.78$ and 3.89 for 0 , $5^{\text {th }}, 10^{\text {th }}$ and $15^{\text {th }}$ days, respectively. For 27 W.s $/ \mathrm{cm}^{2}$ dose, it was 3.64, $3.74,3.83,3.89$ and 3.93 for $0,5^{\text {th }}, 10^{\text {th }}, 15^{\text {th }}$ and $20^{\text {th }}$ day of cold storage, respectively.

The collagen percentages slightly decreased as increased of laser exposure dose and cold storage period for meat samples. The collagen percentage of control samples decreased from 2.29, 1.87 and $1.79 \%$ and sample of $9 \mathrm{~W} . \mathrm{s} / \mathrm{cm}^{2}$ dose; it was $2.22,1.8$ and $1.75 \%$ for $0,5^{\text {th }}$ and $10^{\text {th }}$ days, respectively. For 18 W.s $/ \mathrm{cm}^{2}$ dose, it was $2.15,1.84,1.74$ and $1.68 \%$ for $0,5^{\text {th }}, 10^{\text {th }}$ and $15^{\text {th }}$ days, respectively. For $27 \mathrm{~W} . \mathrm{s} / \mathrm{cm}^{2}$ dose, it was $2.1,1.81,1.72,1.67$ and $1.65 \%$ for $0,5^{\text {th }}, 10^{\text {th }}, 15^{\text {th }}$ and $20^{\text {th }}$ days, respectively.

From the above results, it was found that the higher laser exposure dose lead to the lower rate of moisture content, collagen and protein percentage and the higher $(\mathrm{Mc} / \mathrm{P})$ ratio of treated meat samples.

Fig.(3) shows that the effects of laser exposure dose on chemical compositions (fat content, $\mathrm{pH}$ and TBA values) of meat during cold storage.

The fat content under the laser exposure doses and cold storage conditions was decreased, where the fat percentage of control meat samples decreased from 2.87, 2.76 and $2.42 \%$ and sample of $9 \mathrm{~W} . \mathrm{s} / \mathrm{cm}^{2}$ dose, it was $2.85,2.75$ and $2.41 \%$ for $0,5^{\text {th }}$ and $10^{\text {th }}$ days, respectively. For 18 W.s $/ \mathrm{cm}^{2}$ dose, it was $2.82,2.71,2.6$ and $2.51 \%$ for $0,5^{\text {th }}, 10^{\text {th }}$ and $15^{\text {th }}$ days, respectively. Whereas, for $27 \mathrm{~W} . \mathrm{s} / \mathrm{cm}^{2}$ dose, it was $2.78,2.69,2.57$, 2.49 and $2.44 \%$ for $0,5^{\text {th }}, 10^{\text {th }}, 15^{\text {th }}$ and $20^{\text {th }}$ days of cold storage, respectively. 


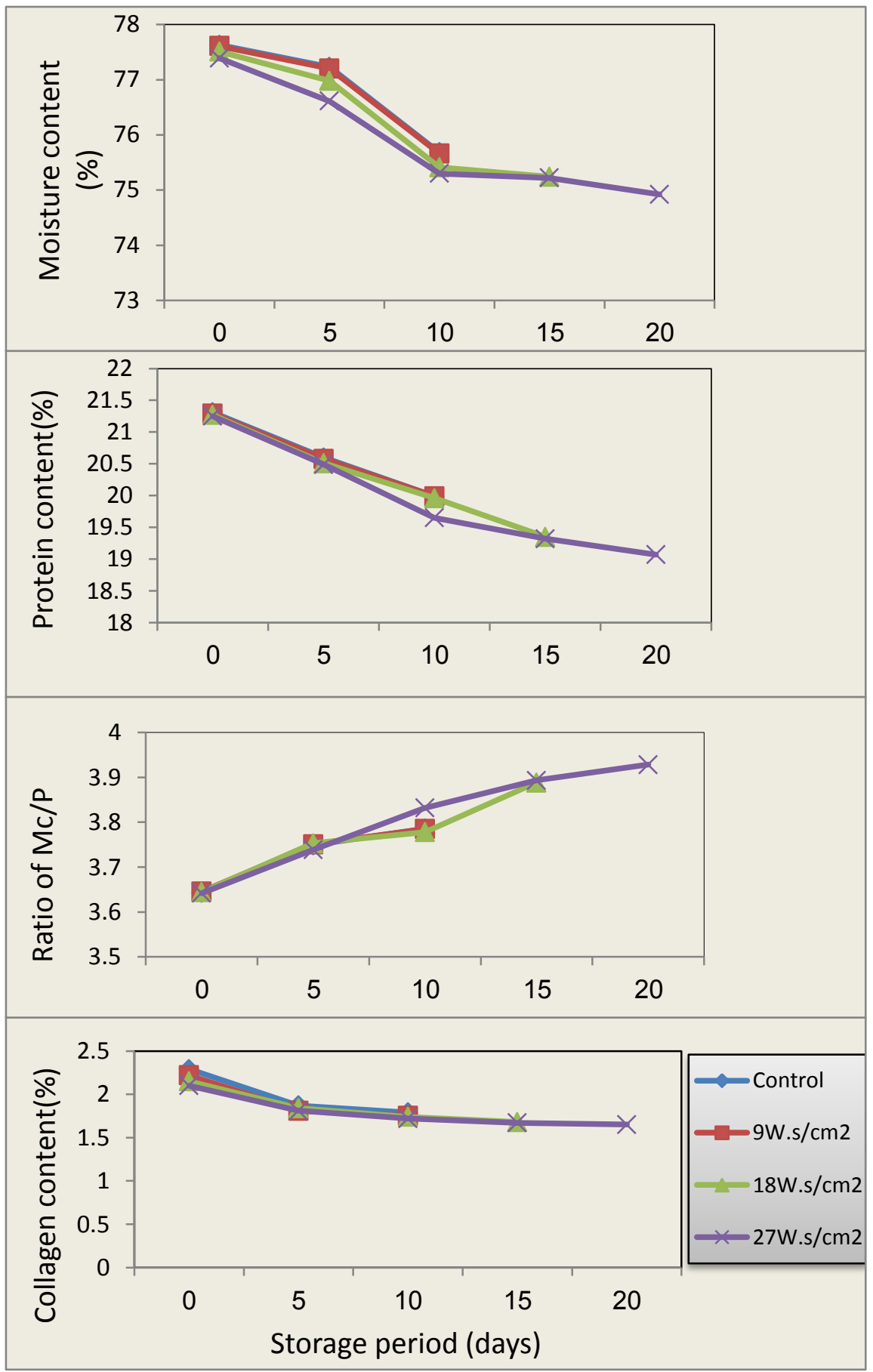

Fig.(2): Effect of laser exposure on moisture content, protein, collagen and $\mathrm{Mc} / \mathrm{p}$ ratio of cattle meat during cold storage. 


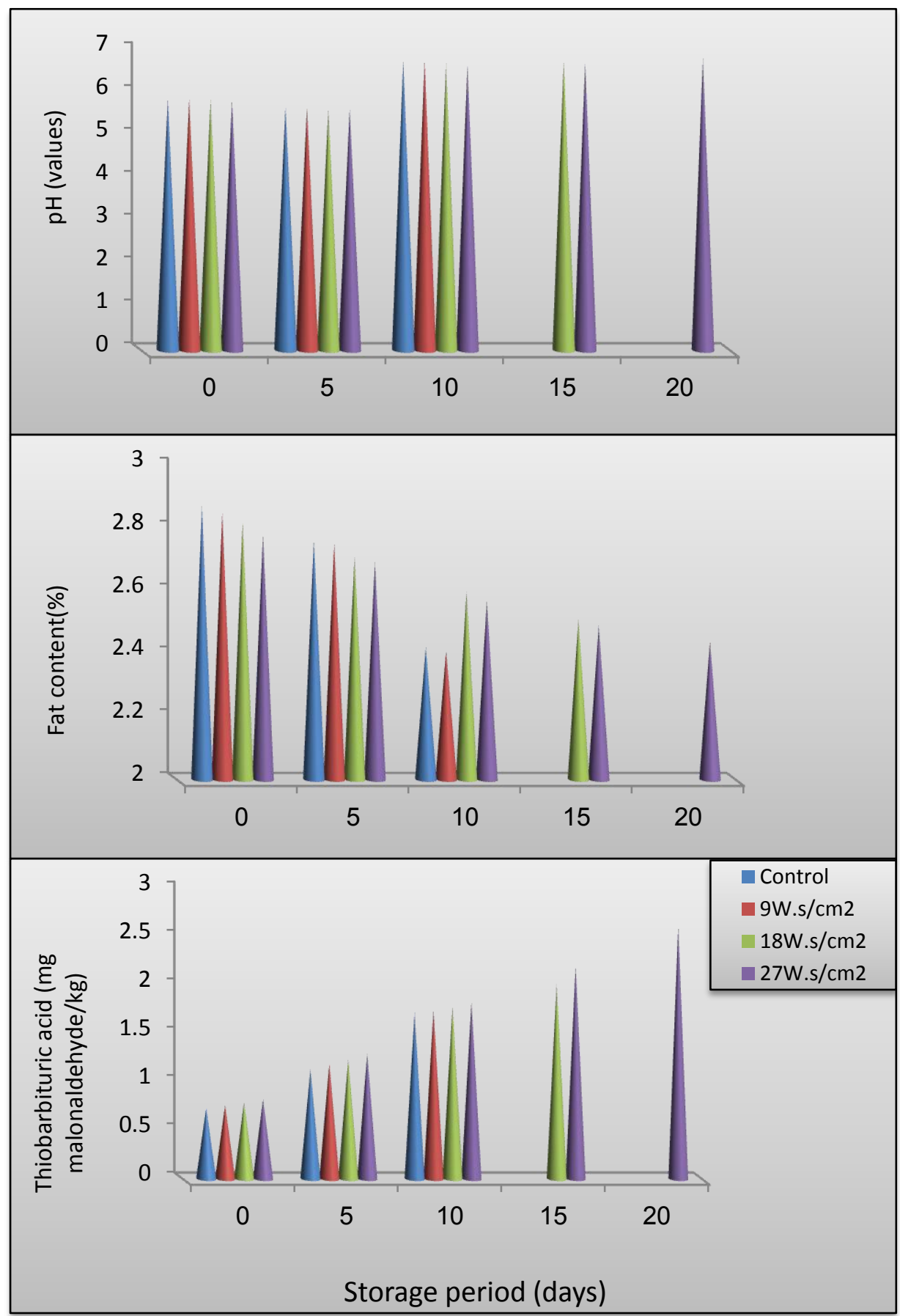

Fig.(3): Effect of laser exposure doses on $\mathrm{pH}$, fat and thiobarbituric acid of cattle meat during cod storage. 
The $\mathrm{pH}$ values of treated samples by laser were lower than the untreated ones and increasing by storage time. The $\mathrm{pH}$ value of control cattle sample increased from 5.86, 5.67 and 6.74 and sample of $9 \mathrm{~W} . \mathrm{s} / \mathrm{cm}^{2}$ dose, it was $5.85,5.66$ and 6.75 for $0,5^{\text {th }}$ and $10^{\text {th }}$ days, respectively. For 18 W.s $/ \mathrm{cm}^{2}$ dose, it was $5.83,5.63,6.68$ and 6.73 for $0,5^{\text {th }}, 10^{\text {th }}$ and $15^{\text {th }}$ days, respectively. For $27 \mathrm{~W} . \mathrm{s} / \mathrm{cm} 2$ dose, it was 5.82, 5.61, 6.65, 6.7 and 6.79 for $0,5^{\text {th }}, 10^{\text {th }}, 15^{\text {th }}$ and $20^{\text {th }}$ days of cold storage, respectively.

The behavior of the thiobarbituric acid values (TBA) of laser exposure meat sample showed progressively increased associated with the higher laser exposure dose; the TBA value of control sample was increased from $0.73,1.13$ and $1.81 \mathrm{mg}$ malonaldehyde $/ \mathrm{kg}$ and sample of $9 \mathrm{~W} . \mathrm{s} / \mathrm{cm}^{2}$ dose, it was $0.76,1.19$ and $1.74 \mathrm{mg}$ malonaldehyde $/ \mathrm{kg}$ for $0,5^{\text {th }}$ and $10^{\text {th }}$ days, respectively. For $18 \mathrm{~W} . \mathrm{s} / \mathrm{cm}^{2}$ dose, it was $0.79,1.23,1.78$ and $2.01 \mathrm{mg}$ malonaldehyde $/ \mathrm{kg}$ for $0,5^{\text {th }}, 10^{\text {th }}$ and $15^{\text {th }}$ days, respectively. For $27 \mathrm{~W} . \mathrm{s} / \mathrm{cm}^{2}$ dose, it was $0.82,1.29, \quad 1.82,2.19$ and $2.61 \mathrm{mg}$ malonaldehyde/kg for $0,5^{\text {th }}, 10^{\text {th }}, 15^{\text {th }}$ and $20^{\text {th }}$ days of cold storage, respectively.

From the above results it was found that, during subsequent cold storage at $4 \pm 1^{\circ} \mathrm{C}$ the fat content and $\mathrm{pH}$ values of cattle meat samples decreased with an inverse relationship to the applied laser exposure doses; while, the TBA values increased progressively associated with the higher laser exposure doses.

Fig.(4) shows that the effect of laser exposure doses on the physical characteristics ( cooking loss, water holding capacity and shear force) of meat samples.

The cooking loss percentage of control meat sample decreased from $46.44,45.21$ and $36.41 \%$ and sample of $9 \mathrm{~W} . \mathrm{s} / \mathrm{cm}^{2}$ dose, it was 46.43 , 45.19 and $36.39 \%$ for $0,5^{\text {th }}$ and $10^{\text {th }}$ days, respectively. For $18 \mathrm{~W} . \mathrm{s} / \mathrm{cm}^{2}$ dose, it was $46.41,45.1,36.13$ and $36.02 \%$ for $0,5^{\text {th }}, 10^{\text {th }}$ and $15^{\text {th }}$ days, respectively. For 27 W.s $/ \mathrm{cm}^{2}$ dose, it was 46.37, 44.95, 36.06, 35.94 and $35.73 \%$ for $0,5^{\text {th }}, 10^{\text {th }}, 15^{\text {th }}$ and $20^{\text {th }}$ days of cold storage, respectively.

The water holding capacity (WHC) of treated samples during cold storage, were lower than the untreated. The WHC percentage of control samples decreased form $77.69,72.66$ and $73.47 \%$ and sample of 9 W.s $/ \mathrm{cm}^{2}$ dose, it was $77.67,72.59$ and $73.46 \%$ for $0,5^{\text {th }}$ and $10^{\text {th }}$ days 


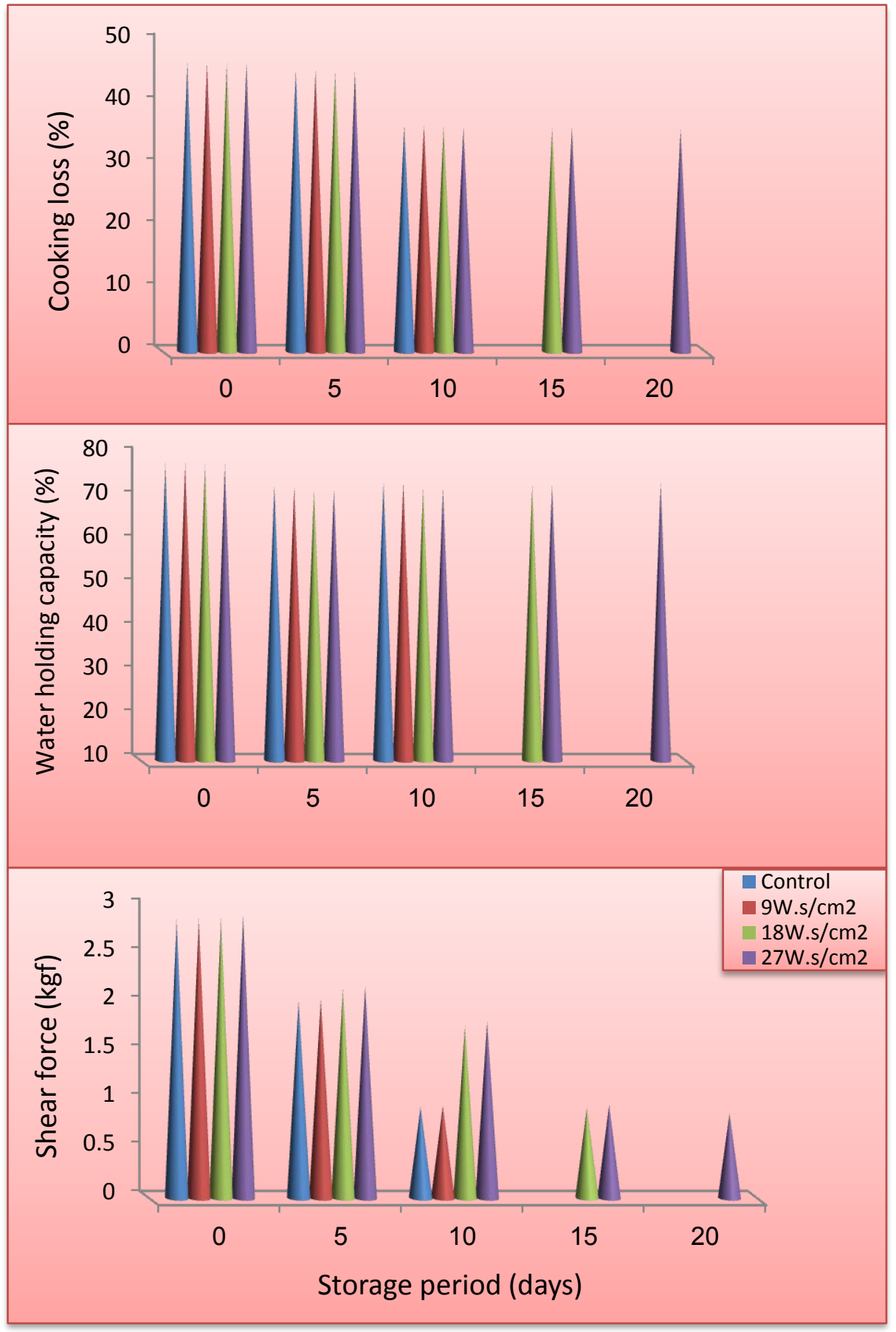

Fig.(4) :Effect of laser exposure doses on cooking loss, water holding capacity and shear force of meat during cold stotage. 
respectively; at $18 \mathrm{~W} . \mathrm{s} / \mathrm{cm}^{2}$ dose achieved values form 77.57, 71.89, 72.35 and $72.82 \%$ for $0,5^{\text {th }}, 10^{\text {th }}$ and $15^{\text {th }}$ days of cold storage, respectively. For $27 \mathrm{~W} . \mathrm{s} / \mathrm{cm}^{2}$ dose, it was $77.49,71.83,72.31,72.78$ and $73.31 \%$ for $0,5^{\text {th }}, 10^{\text {th }}, 15^{\text {th }}$ and $20^{\text {th }}$ days of cold storage respectively.

The shear force value of control sample decreased from 2.86, 2.03 and $0.94 \mathrm{kgf}$ and sample of $9 \mathrm{~W} . \mathrm{s} / \mathrm{cm}^{2}$ dose, it was $2.87,2.05$ and $0.95 \mathrm{kgf}$ for $0,5^{\text {th }}$ and $10^{\text {th }}$ days respectively. For $18 \mathrm{~W} . \mathrm{s} / \mathrm{cm} 2$ dose, it was $2.89,2.16$, 1.77 and $0.93 \mathrm{kgf}$ for $0,5^{\text {th }}, 10^{\text {th }}$ and $15^{\text {th }}$ days, respectively; whereas at 27 W.s $/ \mathrm{cm} 2$ dose, it was $2.91,2.18,1.81,0.96$ and $0.87 \mathrm{kgf}$ for $0,5^{\text {th }}, 10^{\text {th }}$, $15^{\text {th }}$ and $20^{\text {th }}$ days of cold storage respectively.

Form the above data it is noticeably that, the higher laser exposure doses lead to the lower WHC and cooking loss percentages and the higher shear force values of treated beef meat samples

comparison in control sample.

Fig.(5) illustrates that the color attributes of meat as affected by laser exposure doses during cold storage.

The light intensity values of meat sample has been effected by laser exposure doses upon cold storage time; The light intensity value of control sample decreased from 37.21, 29.72 and 29.03value and sample of $9 \mathrm{~W} . \mathrm{s} / \mathrm{cm}^{2}$ dose, it was $37.2,29.71$ and 29.05 value for $0,5^{\text {th }}$ and $10^{\text {th }}$ days, respectively. For 18 W.s $/ \mathrm{cm}^{2}$ dose, it was 36.95, 35.1, 32.25 and 31.02 value for $0,5^{\text {th }}, 10^{\text {th }}$ and $15^{\text {th }}$ days, respectively. By applied of 27 W.s $/ \mathrm{cm}^{2}$ dose, it was $36.89,34.94,32.22,30.88$ and 29.61 value for $0,5^{\text {th }}$, $10^{\text {th }}, 15^{\text {th }}$ and $20^{\text {th }}$ days of cold storage, respectively.

The results show also that, the saturation values of meat sample were increased by the laser exposure doses and decreased during cold storage period, the saturation value of control samples was decreased from 31.05, 22.05 and 19.72 value and for sample of $9 \mathrm{~W} . \mathrm{s} / \mathrm{cm}^{2}$ dose, it was 31.07, 22.01 and 19.73 value for $0,5^{\text {th }}$ and $10^{\text {th }}$ days, respectively. For 18 W.s $/ \mathrm{cm}^{2}$ dose, it was $31.8,23.72,22.68$ and 19.75 value for $0,5^{\text {th }}, 10^{\text {th }}$ and $15^{\text {th }}$ days, respectively. For 27 W.s $/ \mathrm{cm}^{2}$ dose, it was $31.95,23.68,22.79$, 22.06 and 19.76 value for $0,5^{\text {th }}, 10^{\text {th }}, 15^{\text {th }}$ and $20^{\text {th }}$ days of cold storage, respectively. 
The Hue degrees of meat sample were slightly increased by the laser exposure doses during cold storage period. The Hue degree of control sample increased from 25.04, 27.01 and 29.31degree and sample of 9 W.s $/ \mathrm{cm}^{2}$ dose, it was $25.05,27.02$ and 29.32 for $0,5^{\text {th }}$ and $10^{\text {th }}$ days, respectively. For 18 W.s $/ \mathrm{cm}^{2}$ dose, it was $25.31,27.31,28.95$ and 29.42 degree for $0,5^{\text {th }}, 10^{\text {th }}$ and $15^{\text {th }}$ days, respectively. For $27 \mathrm{~W} . \mathrm{s} / \mathrm{cm}^{2}$ dose, it was $25.36,27.39,29.1,29.17$ and 29.55 degree for $0,5^{\text {th }}, 10^{\text {th }}, 15^{\text {th }}$ and $20^{\text {th }}$ days of cold storage, respectively.

From the above results, it was found the higher laser exposure dose lead to the lower light intensity and higher saturation values and hue degrees of treated beef meat samples.

Fig.(5) shows the relationship of total bacterial counts(TBC) in fresh meat at laser exposure doses during cold storage.

The total bacterial count (TBC) of treated and untreated meat samples were gradually increased during cold storage at $4+1{ }^{\circ} \mathrm{C}$ according to the borderline of (Seydim et al., 2006) the maximum values allowed in ground ostrich meat is $10^{7}$ to $10^{8} \mathrm{CFU} / \mathrm{g}$ which associated with an offodor and possible slime development, the total bacterial count of control meat sample increased from $4.2 \times 10^{5}, 3.6 \times 10^{6}$ and $3.1 \times 10^{7} \mathrm{CFU} / \mathrm{g}$ and sample of $9 \mathrm{~W} . \mathrm{s} / \mathrm{cm}^{2}$ dose, it was $1.2 \times 10^{5}, 2.4 \times 10^{6}$ and $.9 \times 10^{7} \mathrm{CFU} / \mathrm{g}$ for $0,5^{\text {th }}, 10^{\text {th }}$ days, respectively. For $18 \mathrm{~W} . \mathrm{s} / \mathrm{cm}^{2}$ dose, it was $7.1 \times 10^{4}$, $6.9 \times 10^{5}, 8.1 \times 10^{6}$ and $2.6 \times 10^{7} \mathrm{CFU} / \mathrm{g}$ for $0,5^{\text {th }}, 10^{\text {th }}$ and $15^{\text {th }}$ days, respectively. For $2 \mathrm{~W} . \mathrm{s} / \mathrm{cm}^{2}$ dose, it was $1.5 \times 10^{4}, 7.4 \times 10^{4}, 9.7 \times 10^{5}$, $8.3 \times 10^{6}$ and $2.6 \times 10^{8} \mathrm{CFU} / \mathrm{g}$ for $0,5^{\text {th }}, 10^{\text {th }}, 15^{\text {th }}$ and $20^{\text {th }}$ days of cold storage, respectively.

From the above results; it was clearing that, the higher laser exposure dose had obvious effect to extend shelf lives and lower TBC rate of treated meat sample, where the extend shelf lives were did not change (5 days) for control and sample of $9 \mathrm{~W} . \mathrm{s} / \mathrm{cm}^{2}$ dose. While, shelf lives were 10 and 15 of $18 \mathrm{~W} . \mathrm{s} / \mathrm{cm}^{2}$ and $27 \mathrm{~W} . \mathrm{s} / \mathrm{cm}^{2}$, respectively. But, the meat sample of control, 9, 18 and $27 \mathrm{~W} . \mathrm{s} / \mathrm{cm}^{2}$ were rejected at $10,10,15$ and 20 day, respectively. 


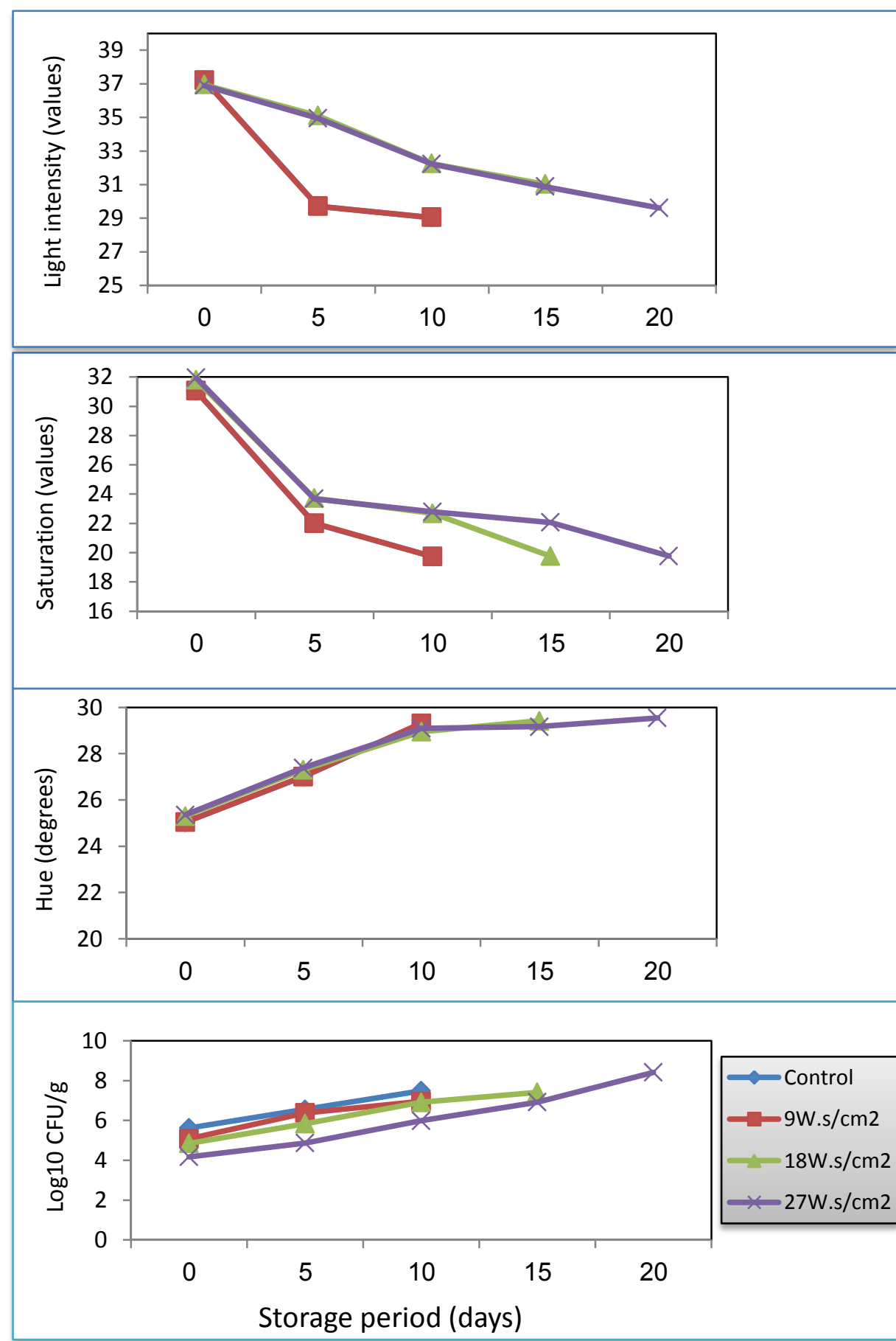

Fig.(5): Effect of laser exposure doses on color attributes (light intensity, saturation values and Hue degree) and total bacterial count of cattle meat during cold storage. 
PROCESS ENGINEERING

\section{CONCLUSIONS:}

The results of the present study can be summarized as follows:

1) Laser beam was leaded to reduce the total account of microorganisms $1.2 \times 10^{5}, 7.1 \times 10^{4}$ and $1.5 \times 10^{4} \mathrm{CFU} / \mathrm{g}$ for 9,18 and $27 \mathrm{~W} . \mathrm{s} / \mathrm{cm}^{2}$, respectively. Meanwhile, shelf lives were did not change (5 days) for control and sample of $9 \mathrm{~W} . \mathrm{s} / \mathrm{cm}^{2}$ dose. While, shelf lives were 10 and 15 of $18 \mathrm{~W} . \mathrm{s} / \mathrm{cm}^{2}$ and $27 \mathrm{~W} . \mathrm{s} / \mathrm{cm}^{2}$, respectively.

2) For the chemical properties the moisture content decreasing from 77.63 to $77.61,77.51$ and $77.39 \%$; protein content from 21.31 to $21.29,21.27$ and $21.25 \%$; collagen content from 2.29 to $2.22,2.15$ and $2.1 \%$ and fat content form 2.87 to $2.85,2.82$ and $2.78 \%$; $\mathrm{pH}$ values from 5.86 to 5.85 , 5.83 and 5.82. Meanwhile, there were increasing at TBA values from 0.73 to $0.76,0.79$ and $0.82 \mathrm{mg}$ malonaldehyde $/ 1 \mathrm{~kg}$ by laser exposure during cold storage period days for control and laser exposure doses 9, 18 and 27 W.s/ $\mathrm{cm}^{2}$ respectively.

3) The physical parameters like cooking loss were slightly decreasing from 46.44 to $46.43,46.41$ and $46.37 \%$; water holding capacity was from 77.69 to $77.67,77.57$ and $77.49 \%$. Meanwhile, the share force was increased form 2.86 to $2.87,2.89$ and $2.91 \mathrm{kgf}$ for control and laser exposure doses 9,18 and $27 \mathrm{~W} . \mathrm{s} / \mathrm{cm}^{2}$ of treated beef samples during cold storage respectively.

4) For color properties laser irradiated samples had higher Hue degree from 25.04, 25.05, 25.31 and 25.36 degree and saturation values from 31.05 to $31.07,31.8$ and 31.95. Meanwhile, lightness values decreased from 37.21 to $37.2,36.95$ and 36.89 for control and laser exposure doses 9,18 and $27 \mathrm{~W} . \mathrm{s} / \mathrm{cm}^{2}$ respectively.

5) It was concluded that laser beam had obvious impacts on microbial quality, extend shelf-life, chemical and physical parameters and color attributes of fresh cattle meat during cold storage.

\section{REFERENCES:}

Abdul-Aziz, M. E. (2006). Effect of some cryprotecant agents on physicochemical properties of frozen stored Bolti (Tilapia Nilotica) fish fillets. MSc. Thesis Faculty of Agriculture, Cairo University. Pp.: 198. 
Adams M. R. and M. O. Moss (2008). Food microbiology. Issues in environmental science. The royal society of chemistry. Cambridge UK, ISBN 978-0-85404-284-5. Pp.: 460.

Aleksić, S.; M. M. Petrović; V. Pantelić; Ž. Novaković; D. OstojićAndrić; N. Stanišić and D. Nikšić (2011). Chemical, technological and sensory properties of meat from different cattle genotypes. 3rd International Congress "New perspectives and challenges of sustainable livestock production", biotechnology in animal husbandry. 27: 913-918.

Al-Watban, F. A. H.; X. Y. Zhang and B. L. Andres (2007). Lowlevel laser therapy enhances wound healing in diabetic rats: a comparison of different lasers. Journal of photo-medicine and laser surgery. 25(2):72-77.

Ameral, I. C.; R. A. Braga; E. M. Ramos; A. L. S. Ramos and E. A. R. Roxael (2013). Application of bio-speckle laser technique for determining biological phenomena related to beef aging. Journal of Food Engineering. 119(1):135-139.

Balkenius, C.; A. J. Johansson and A. Balkenius (2003). Color constancy in visual scene perception Lund university cognitive studies, Sweden. Lucs. 98.Issn 1101-8453. Pp.:1-7.

Commission International de I, $E^{\prime}$ clairage (CIE) (1976). Official recommendation on uniform color spaces. Color differences equation and metric color terms. Suppl. No. 2. CIE Publication No.15 Colourimetry. Paris. Pp.: 17-19.

Cozzolino, D. and I. Murray(2004). Identification of animal meat muscles by visible and near infrared reflectance spectroscopy Lebensmittel-Wissenschaft und Technologie, 37 (4):447- 452.

Du, C. J. and D.W. Sun (2005). Correlating shrinkage with yield, water content and texture of Pork ham by computer vision. Journal of Food Process Engineering, 28: 219-232.

Escalona, V. H.; E. Aguayo; G. B. Martinez-Hernandez and F. Artés (2010). UV-C doses to reduce pathogen and spoilage bacterial 
growth in vitro and in baby spinach. Postharvest Biology and Technology. 56: 223-231.

Gap-Don, K.; J. Eun-Young; L. Hyun-Jung; Y. Han-Sul ; J. SeonTea and J. Jin-Yeon (2013). Influence of meat exudates on the quality characteristics of fresh and freeze-thawed pork. J. Meat Science. 95(2): 323-329.

International Organization for Standardization (ISO), 4833 (2003). Microbiology of food and animal feeding stuffs horizontal method for the enumeration of microorganisms, colony count technique at $30^{\circ} \mathrm{C}$. Geneva, Switzerland. Pp.:166-172.

Marcos, B.; P. Gou; M. D. Guàrdia; M. Hortós; M. Colleo; N. Mach ;M. F. W. Te-Pas; E. Keuning; L. Kruijt; J. Tibau; M. Gispert and J. Arnau (2013). Surface-enhanced laser desorption/ionization time of flight mass spectrometry: A tool to predict pork quality. J. Meat Science. 95(3):688-693.

Perez-Marın, D.; E. De Pedro-Sanz; J. E. Guerrero-Ginel and A. Garrido-Varo (2009). A feasibility study on the use of nearinfrared spectroscopy for prediction of the fatty acid profile in live Iberian pigs and carcasses. Meat Science. 83(4):627-633.

Sami, A. S. (2001). Performance of fattening bulls fed diets supplemented with protected fat. Ph.D. Thesis, Faculty of Agriculture, Cairo University, Egypt. Pp.:107.

ShackeLford, S. D.; T. L. Wheeler and M. Koohmaraie (2004). Evaluation of sampling, cookery and shear force protocols for objective of lamb- Longissimus tenderness. J. of Animal Science. 82:802-807.

Schmidt, H.; R. Scheier and D. L. Hopkins (2013). Preliminary investigation on the relationship of Raman spectra of sheep meat with shear force and cooking loss. Meat Science. 93(1):138-143.

Sommers, C.H.; J. Sitesand M. Musgrove (2010). Ultraviolet light (254nm) inactivation of food borne pathogens on foods and stainless steel surfaces. Journal of Food Safety. 30(2): 470-479. 
U.S. Department of Agriculture (USDA) and foreign agriculture service (2013). Gain report, global agriculture information network. Pp.: 5-10.

Vyncke, W. (1970). Direct determination of thiobarbituric acid value in trichloroacetic acid extracts of fish as measure of oxidative rancidity. Fette. Seifen. Anstichmittel. 72(12):1084-1087.

Wang, W. and C. Li (2013). Measurement of the light absorption and scattering properties of onion skin and flesh at $633 \mathrm{~nm}$.Postharvest Biology and Technology. 86: 494-501.

Williams, P. (2007). Nutritional composition of red meat, Nutrition and Dietetics. The Journal of the Dietitians of Australia. Pp.:123-126.

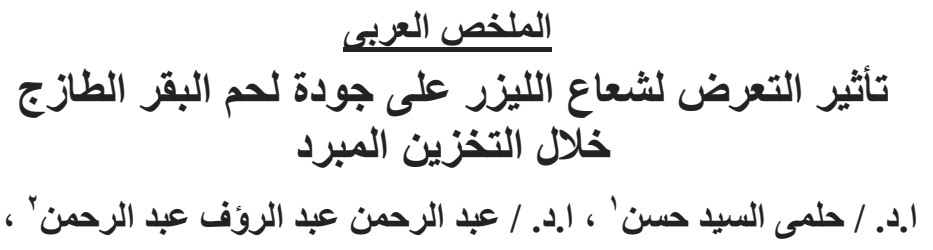

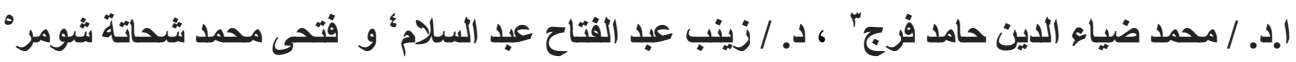

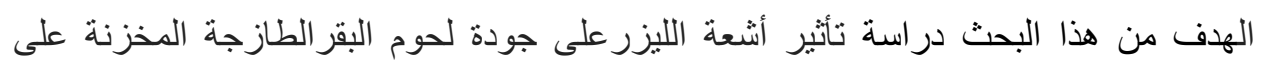

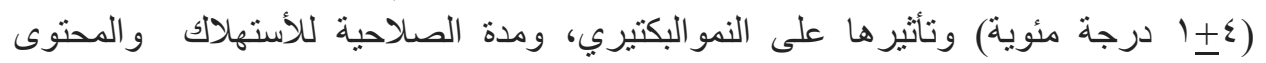

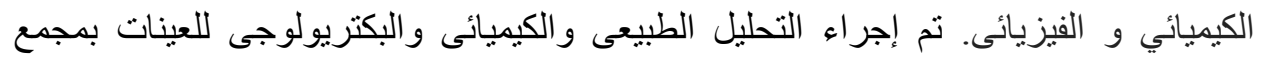

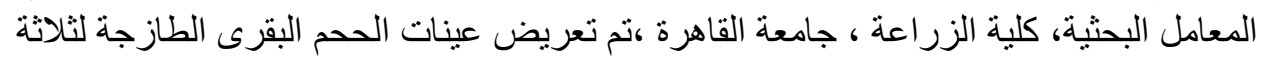

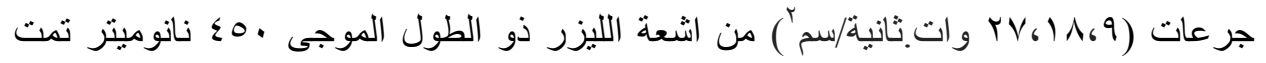

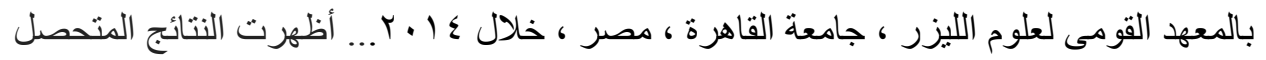

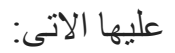

( ) لم يحث تغير فى العدد الكلى للكائنات الحية الدقيقة في عينات اللحم البقرى الغير معاملة

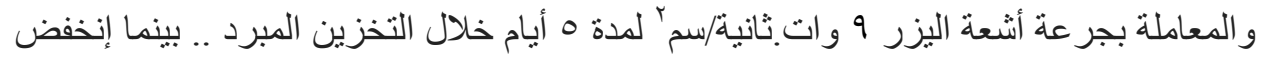

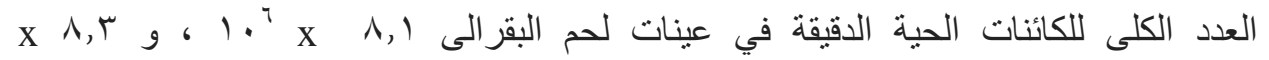

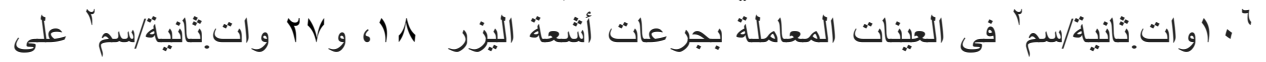

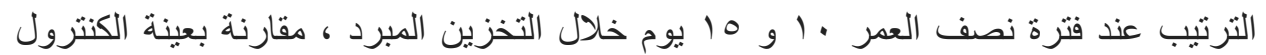

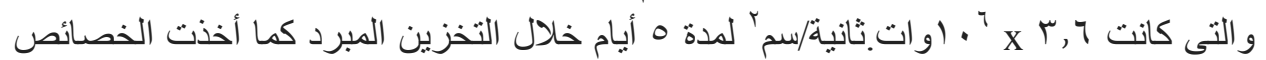
الفيزوكيميائية نفس الأتجاة.

\footnotetext{
1. أستاذ الهندسة الزراعية ـ المعهد القومى لعلوم الليزر - جامعة القاهرة ـ مصر.

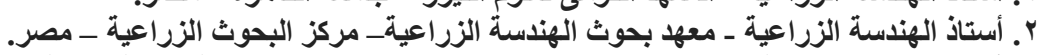

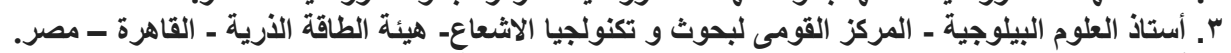

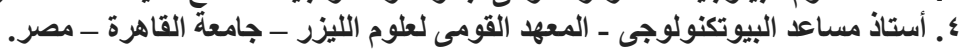

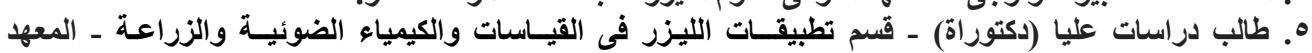
القومى لعلوم الليزر - جامعة القاهرة - مصر.
} 


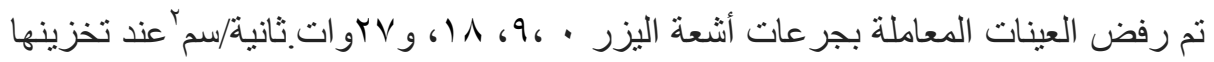

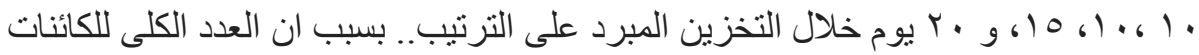

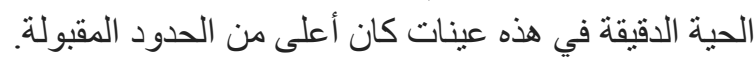

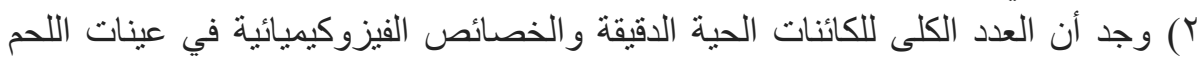

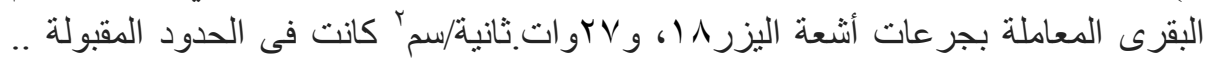

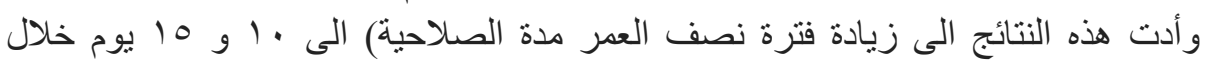
التخزين المبرد، مقارنة بعينة الكنترول و التى كانت ه أيام خلادل التخزين المبرد.

r) نستنتج أن أشعة الليزر ذات تأثير واضح على خفض المحتوى البكتيري واطالة عمر اللحم البقرى (فترة الصلاحية للأستهلاك) ، وعدم حدوث تغيير ملحوظ فى الخصائص

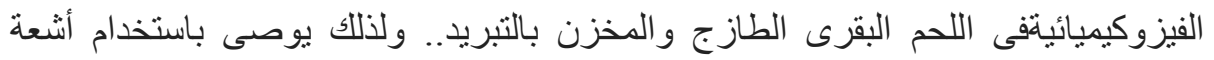

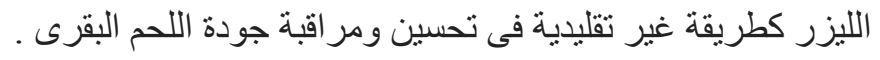

